\title{
MICHAEL OAKESHOTT
}

O postępowaniu człowieka (On Human Conduct)

Przeł. Michał Szczubiałka

Wydawnictwo Naukowe PWN, Warszawa 2008, ss. 373

\section{MARCIN POLAKOWSKI}

Instytut Politologii UMK

\section{Państwo sceptyka}

ydana niedawno nakładem Wydawnictwa Naukowego PWN praca Michaela Oakeshotta 0 postępowaniu człowieka (On Human Conduct) jest drugą książką tego myśliciela dostępną w języku polskim. Po zbiorze esejów przetłumaczonym $\mathrm{u}$ schyłku poprzedniego wieku ${ }^{1}$, czytelnik dostaje do rąk publikację niezwykle ważną, która wedle samego autora stanowić miała zebranie w całość myśli, które - jak sam pisał - towarzyszyły mu od samego początku jego refleksji. Przez myśli należy rozumieć tutaj rozważania polityczne - 0 postępowaniu człowieka traktowane jest jako podsumowanie i dojrzały wyraz filozofii politycznej Oakeshotta. Rzeczywiście, ostatni wydany za jego życia zbiór esejów On History and Other Essays (1983) nie dotyczył już bezpośrednio zagadnień filozoficzno-politycznych, lecz raczej filozoficznohistorycznych.

Omawiana praca, opublikowana w oryginale w roku 1975, wyróżnia się pewną swoistą formą. Z jednej strony wydaje się być jedną z niewielu publikacji zwartych w dorobku angielskiego myśliciela, z drugiej zaś - co podkreśla sam autor w przedmowie - składa się z ulubionej przez niego formy, czyli eseju. Jednak o ile wcześniej były one publikowane zazwyczaj w zbiorach o dość słabej spójności tematycznej, o tyle tym razem są ze sobą wyraźnie silniej związane.

Esej pierwszy, wprowadzający do dalszych rozważań, może zaskakiwać i pozornie nie koresponduje z zapowiadanym tematem książki. Stanowi on bowiem swoisty metodologiczny wstęp, ogólny (ale precyzyjny) słownik,

M. Oakeshott, Wieża Babel i inne eseje, przeł. A. Lipszyc, Ł. Sommer, M. Szczubiałka, Warszawa 1999, ss. 298. 
na podstawie którego Oakeshott konsekwentnie buduje swoje koncepty. Jest to o tyle osobliwe, że angielski filozof był przypadkiem myśliciela, którego styl w niemal każdej wcześniejszej pracy odznaczał się dużą enigmatycznością, poetyckimi metaforami czy narracją przypominającą raczej opowieść aniżeli wywód naukowy. Tym razem jest inaczej. Oakeshott nie ubarwia toku swojego rozumowania nadmiernymi ozdobnikami. Mozolnie konstruuje autorski (dość swoisty) wokabularz i konsekwentnie go używa. Rozwija swoją teorię od najprostszych zagadnień, krok po kroku postępując dalej i często podsumowując kolejne etapy.

Jak wskazuje sam tytuł pierwszej części - O rozumieniu teoretycznym postępowania człowieka - angielski myśliciel zajmuje się w niej zagadnieniami fundamentalnymi, dotyczącymi tego, czym jest rozumowanie, postępowanie czy wreszcie teoretyzowanie i jakie zachodzą między nimi relacje. Szczególnie istotne wydaje się tu przedstawienie postaci teoretyka oraz teoretycznego badania postępowania człowieka, jako „bezwarunkowego, krytycznego zaangażowania rozumienia", którego wyrazem są teorematy, będące zrozumieniem warunkowości pojęć powszechnych, czyli wyników dociekania w ramach pewnych postulatów. Rozumień potocznych (powszechnych) i owoców badania teoretycznego nie dzieli przepaść. Nie jest to relacja doxai i episteme, opinii i wiedzy ${ }^{2}$; rozumienia powszechne nie mają charakteru mniemań, „zrozumiałości zarazem tak zupełnej i tak minimalnej, że przekreślanej jako niewiedza"3. Jest to, rzecz jasna, rozumienie warunkowe, w tym sensie ograniczone i spętane, a jednak niezbędne w porządku praktyki ludzkiej. Teoretyzowanie zaś to jedynie zrozumienie i odkrycie charakteru, kształtu warunkowości rozumowania dokonywanego $\mathrm{w}$ ramach pewnych postulatów. Rozumienie ostateczne, „w którym świat staje się bezwarunkowo zrozumiały”, „bezwarunkowe rozumienie świata w ramach jego ostatecznych postulatów" oczywiście góruje nad rozumieniem potocznym, nad cieniami platońskiej jaskini, lecz po pierwsze samo pojęcie „rozumienia bezwarunkowego" z uwagi na swój wizjonerski charakter rodzi wiele trudności, a ponadto wątpliwe jest, czy to rzeczywiście dar „o nieocenionej wartości”, „,rozumienie i język ostateczny”, ,zupełny «substytut» tamtego i każdego innego rozumienia warunkowego" i czy w ogóle odgrywa jakąkolwiek rolę w przygodzie teoretyka. To, co wydaje się poznaniem ostatecznym, częstokroć okazuje się bowiem tylko kolejnym rozumowaniem warunkowym, tyle że warunkowość jest w tym przypadku dalece mniej wyraźna. Nie ma

Por. L. Strauss, Czym jest filozofia polityki?, w: tenże, Sokratejskie pytania, przeł. P. Maciejko, Warszawa 1998, s. 61-62.

3 M. Oakeshott, O postępowaniu człowieka, przeł. M. Szczubiałka, Warszawa 2008, s. 39. 
więc sensu przerywanie aktywności teoretyzowania, raczej każde kolejne rozumienie winno być rozpoznawane jako jeszcze-nie-zrozumiane, jako zaproszenie do zrozumienia. Absolutystyczna postawa filozofa, nakierowana na ostateczne poznanie obiektywnej natury wszechrzeczy, traci sens ostateczny. Choć odważna ucieczka teoretyka z platońskiej jaskini również nie dokonuje się bez czegoś w rodzaju „zerwania pęt”, wyzwolenia się z „idiomu rozumienia właściwego mieszkańcom jaskini”, to jego zadanie postrzegać należy raczej jako aktywność wytrawnego kartografa i wprawnego diagnostyka, sprawnego lecz skromnego, zapewne niezrozumianego, ale nie narażającego się na stanie się odrzuconym „teoretykierem”. Oakeshott usilnie i konsekwentnie unika słowa filozofia, teoretyka (warunkowego) nazywa co najwyżej „filozofem”. Teoretyzowanie nie jest aktywnością zorientowaną na cel, ile raczej praktyką autoteliczną, wartościową samą w sobie, a jej cel zawiera się w niej samej. Ogółu wiedzy filozoficznej nie sposób oderwać od samej czynności filozofowania ${ }^{6}$.

W drugim eseju swojej pracy, zatytułowanym 0 stanie cywilnym, Oakeshott definiuje typ więzi międzyludzkiej nazywanej cywilną, która jest pewną postacią idealną stanu określanego również jako civitas, w którym ludzi określa się mianem cives, pojęcia tej więzi lex, zaś ogólne warunki stowarzyszenia - mianem respublica. W ten sposób zostaje podkreślona abstrakcyjność i modelowość tego stanu, gdyż angielski filozof używa wspomnianych pojęć głównie ze względu na ich archaiczność i niezapośredniczenie w rozumieniach terminów współczesnych, jak sprawiedliwość, polityka, rządy, poddany czy panowanie. Stan cywilny ma wynikać z właściwego zrozumienia ograniczeń postępowania ludzkiego. Lex usprawiedliwia więc orzeczenia rozstrzygające spory w ramach civitas, jednak reguły wewnętrzne są tylko formą pewnego wspólnego języka zbiorowości, nie przesądzają więc o „prawdzie, całej prawdzie i tylko prawdzie". Stowarzyszenie cywilne zostaje odróżnione od stowarzyszenia przedsięwzięcia, które odznacza się substancjalnym ce-

\footnotetext{
Tamże, s. 38-42.

Samo zdystansowanie od klasycznego rozumienia misji filozofii nie wydaje się u Oakeshotta czymś nowym, choć w żadnej wcześniejszej pracy nie zostało chyba wyrażone równie jasno. Nawiązując do wcześniejszych prac Oakeshotta, jeśli w „rozmowie ludzkości" uczestniczą różne głosy: historii, nauki, poezji i praktyki, to filozofia jest jedynie „odruchem badania własności i stylu każdego z tych głosów oraz refleksji na temat ich wzajemnych odniesień". Tenże, Poezja i jej głos w rozmowie ludzkości, w: tenże, Wieża Babel..., s. 246. Jak przyznaje sam autor, jeśli chodzi o porządek rozmowy „rezygnacja z hierarchicznego porządku głosów (...) oznacza odejście od najznakomitszych tradycji myśli europejskiej". Tamże, s. 247. Teoretyzowanie wykazuje wiele cech charakteryzowanej wcześniej filozofii (politycznej) jako refleksji „radykalnie burzycielskiej”. Tenże, Filozofia polityki, w: tamże, s. 119-123.

6 Tenże, Poezja i jej głos..., s. 247.
} 
lem, determinującym nie tylko granice takiego stowarzyszenia, warunki przynależności do niego, ale preferuje również określone sposoby postępowania i typy relacji międzyludzkich, nakierowanych na cel i temu celowi podporządkowanych.

O ile w drugim eseju Oakeshott stawia sobie za zadanie opisać typy idealne stowarzyszeń międzyludzkich, o tyle w eseju ostatnim (o postaci nowożytnego państwa europejskiego) próbuje dokonać historycznej egzemplifikacji tego opisu na przykładzie historii nowożytnego państwa europejskiego. Próbując nakreślić skrótowo rys wyłaniania się tego typu państwa z uniwersum średniowiecznego, opisuje je jako pewną formę więzi zbiorowej, której uczestnicy są „wolnymi sprawcami”, inaczej mówiąc, ludźmi nowożytności, pełnymi hobbesowskich pragnień i pożądań, których w zbiorowości nie łączy z innymi żaden wspólny cel czy interes, lecz co najwyżej pewne wspólne praktyki, rzadko kiedy jednak identyczne i obejmujące wszystkich. Państwo takie może przyjmować najróżniejsze formy, zasadniczo jednak oscyluje pomiędzy dwiema skrajnościami; ideą państwa ujmowanego jako societas oraz universitas. Societas jest niczym innym niż historyczną próbą utrzymywania więzi właściwej dla civitas (stowarzyszenia cywilnego), a więc nie „więzią zaangażowania w przedsięwzięcie dążenia do jakiegoś wspólnego rzeczowego celu ani umacniania jakiegoś wspólnego interesu, lecz więzią wzajemnej lojalności, której warunki mogą osiągnąć formalizm oznaczany pokrewnym słowem "legalność»"7. Jest to lojalność wobec pewnych reguł, uznanie ich autorytetu, będącego głównym owocem paktu obywateli. Universitas to natomiast więź pojawiająca się w ramach nowożytnej historii Europy, która determinuje powstanie rządów o charakterze teleokratycznym, celowościowym. Cel takiego społeczeństwa jednoczy wielu sprawców w zbiorowość, w której każde działanie, relacja, praktyka czy więź nie jest traktowana autotelicznie, jako cel sam w sobie, lecz jako środek do celu.

Tak pojęta krytyka celowości jest jednym z najważniejszych rysów książki, jednak w szerszym kontekście stanowi ona ważny rys całej filozofii Oakeshotta. Zakładanie konkretnej koncepcji celowości ludzkiego istnienia i działania, stanowi samo w sobie niezwykle silną pokusę „kierowniczej troski o cel", autorytatywnie wskazującej nie tylko jego ogólny zarys, majaczący na horyzoncie, lecz wyznaczającej ściśle określony sposób działania, umożliwiający nam jego niezawodną realizację ${ }^{8}$. W tak utrwalonym sposobie pojmowania racjonalności, sposób działania oznacza pewne określone czynności, inne zaś, niepasujące do wzorca bezwzględnie wyklucza. Odnosi się to

Tenże, O postępowaniu..., s. 228.

Tenże, Postępowanie racjonalne, w: tenże, Wieża Babel..., s. 89-118. 
zarówno do racjonalizmu w polityce, a więc do porządku zbiorowego ${ }^{9}$, jak i do życia jednostki ${ }^{10}$, choć $\mathrm{w}$ tym pierwszym przypadku jest ono oczywiście nieporównanie dalece bardziej niebezpieczne i niszczące. Sformułowanie teorii stowarzyszenia cywilnego $\mathrm{w}$ kontrze do stowarzyszenia przedsięwzięcia nie jest więc zmianą jakościową w twórczości Oakeshotta, lecz co najwyżej kontynuacją wcześniej podjętych tropów intelektualnych.

Wypada się zatem zastanowić, czy krytyka celowościowego działania człowieka, w powiązaniu z wcześniej odnotowanym sceptycznym stanowiskiem w większości kwestii metateoretycznych oraz historycyzacją wszelkiej refleksji, pozwala sytuować Oakeshotta w ramach tradycji myślenia o polityce nawiązującej do źródeł przednowożytnych, czyli najogólniej rzecz ujmując do nurtu konserwatywnego, do którego bardzo często - zwłaszcza w literaturze polskojęzycznej - jest on przypisywany. Po lekturze 0 postępowaniu człowieka wydaje się to niezwykle problematyczne. O ile wcześniejsze eseje angielskiego myśliciela zestawiano często z innymi umiarkowanymi krytykami ekscesów oświeceniowego ratio i jego politycznych konsekwencji, o tyle po tej książce wydaje się to dalece wątpliwe. Sceptycyzm Oakeshotta, wyrażony w eleganckiej formie, wydaje się bowiem dużo silniejszy i sięga de facto w najgłębsze zdroje tradycji europejskiej. Autor recenzowanej książki polemizuje w sprawach fundamentalnych zarówno z Platonem (np. wizja filozofii i roli filozofa), Arystotelesem (np. krytyka celowości tak charakterystycznej dla filozofii Stagiryty) czy klasyczną chrześcijańską filozofią i teologią polityczną (np. całkowita negacja koncepcji prawa naturalnego), co bezpośrednio przekłada się na jego projekty polityczne. Oakeshott nie tyle czerpie mniej z tradycji filozofii klasycznej czy chrześcijańskiej, niż wielu jawnych konserwatystów czy filozoficznych miłośników myślenia klasycznego, lecz wydaje się - jako się rzekło - przynajmniej redefiniować podstawowe intuicje tradycji intelektualnej Europy. Choć nie czyni tego całościowo, to jednak przemiany nowożytne - niewątpliwe i głębokie - nie są dla niego radykalnym zboczeniem z drogi prawdziwej, nie są ",schizmą bytu”, nie są gnostycznym buntem przeciwko rzeczywistości - takie możliwości w ogóle nie są przez angielskiego myśliciela brane pod uwagę. Używając charakterystycznego dla Oakeshotta języka, jego współpielgrzymami w wędrówce, czy też równoprawnymi partnerami w rozmowie, są nie tylko Platon czy Arystoteles, Seneka czy Cyceron, Augustyn czy Akwinata (choć i do nich w pewnych elementach nawiązuje), lecz również Hobbes, Montaigne, Monteskiusz czy

Tenże, Racjonalizm w polityce, w: tamże, s. 21-58

10 Przykładowo krytyka moralności opartej na dążeniu do ideału nie tylko jest zabójcza dla społeczeństwa, ale i niebezpieczna dla jednostki, w przeciwieństwie do moralności zgodnej z obyczajem. Tenże, Wieża Babel, w: tamże, s. 221-242. 
Hegel. Przemiany nowożytne są więc dziedzictwem, które należy przyjąć, nawet jeśli jednocześnie zdajemy sobie sprawę z ich bolączek. Niechęć Oakeshotta do wszelkich utopii (w tym retrospektywnych), zasadzona na silnym przekonaniu o wzajemnym i nie do końca możliwym do przeniknięcia wzajemnym oddziaływaniu i wpływie na siebie sfery idei i praktyki ${ }^{11}$, nie pozwala mu na formułowanie ambitnych programów i dopuszcza zawsze jedynie częściową krytykę zastanej rzeczywistości. Wiedza, raczej tworzona niż odkrywana, zawsze jest zapośredniczona przez konkretne historyczne doświadczenie ${ }^{12}$, dlatego też sens traci zarówno absolutyzowanie konkretnych warunków, jak i ich całkowite potępianie. Również nowożytność, choć według Oakeshotta wyznacza warunki graniczne teoretyzowania o polityce, jest czymś nietrwałym i przygodnym. Przekłada się to na koncepcje zaprezentowane w recenzowanej książce.

Koncepcja polityki, jaką angielski myśliciel prezentuje, jest więc jedynie propozycją przystającą do czasów nowożytnych, teoria uniwersalna zupełnie go nie interesuje. Angielski teoretyk, jak się wydaje, oddziela sferę polityczności od innych form ludzkiej aktywności, sugeruje też, iż jest to obszar w jakimś stopniu immanentnie zagrożony wulgarnością i groźbą permanentnego upraszczania ludzkiego istnienia. Człowiek realizuje się w sferze osobistych relacji z innymi, niekoniecznie jednak w porządku abstrakcyjnej wspólnoty narodowej czy państwowej - indywidualizacja jest zbyt głęboka i niemożliwa do świadomego odwrócenia. Polityka odnosząca się do porządku zbiorowego jest zawsze czynnikiem wtórnym wobec zasobów cywilizacji, świata relacji, praktyk i aktywności, napędzanych przez wolne sprawstwo człowieka. W tym sensie polityka, choć jest oczywiście więzią o charakterze moralnym, nie może być w obecnych warunkach uniwersalną, przekładalną na życie każdego człowieka propozycją etyczną. Formalistyczne ujęcie autorytetu politycznego, starannie oddzielonego od innych sfer ludzkiej aktywności w świecie, jest jedynie próbą stworzenia statycznego modelu, do którego niekiedy zbliża się ciągle przeobrażające się i poszukujące własnej formuły wyrazu nowożytne państwo europejskie. Tak oto stowarzyszenie cywilne, którego societas jest $\mathrm{w}$ porządku historycznym jedynie pewnym refleksem, jest lepsze od stowarzyszenia przedsięwzięcia, w porządku historyczno-instytucjonalnym bliższym universitas, gdyż jest więzią lepiej zabez-

11 Por. Tenże, On Misunderstanding Human Conduct: A Reply to My Critics, „Political Theory”, Vol. 4, No. 3, 1976, s. 354-355.

12 „Tak więc nie może istnieć żadne absolutne odróżnienie «faktu» i «teorematu». Fakt nie ma w sobie żadnej ostateczności ani żadnej zwierzchności w stosunku do późniejszych przygód na drodze rozumienia: jest pewnym pierwszym i warunkowo akceptowalnym rozumieniem danego «dziania-się». Tenże, o postępowaniu..., s. 12. 
pieczającą przetrwanie stowarzyszenia w warunkach nowożytnych. Służy jedynie ochronie porządku w ramach warunków wyznaczanych przez nowożytność europejską, przez nieredukowalne (ale i niemożliwe do ujęcia w model ustrojowy) doświadczenie wolności oraz autonomii jednostki, nie jest jednak ucieleśnieniem jakiejkolwiek substancjalnej koncepcji dobra, nie partycypuje w obiektywnej naturze rzeczy. Nie jest porządkiem uniwersalnym czy prawdziwym, trudno nawet stwierdzić, czy w jakikolwiek sposób jest lepsze od koncepcji politycznych innych czasów i innych warunków. Nie ma charakteru butnej odpowiedzi na doświadczenie chaosu ludzkich żądań i dążeń, jakie wybuchły u progu nowożytności wraz z rozpadem średniowiecznej wspólnoty ${ }^{13}$. Programowo odrzuca pokusę hybris, nie odrzuca więc doświadczenia supranaturalnego czy metafizyki, co jest udziałem wielu projektów nowożytnych, ale wyraźnie sytuuje je poza obszarem teoretyzowania, a więc i polityki ${ }^{14}$. Nie postrzega ich jako źródła inspiracji dla rozważań o sprawach ludzkich, lecz jednocześnie pozostawia jako ogólną perspektywę, tajemnicę ograniczającą ludzkie działanie, w tym dziedzinę rządzenia.

Książka 0 postępowaniu człowieka niewątpliwie jest ciekawą syntezą rozważań filozoficzno-politycznych, które Oakeshott prowadził od początku swojej działalności. Zbiera wiele wątków porozrzucanych po dziesiątkach esejów i tworzy z nich spójny obraz, dający podstawowy wgląd w poglądy angielskiego myśliciela na to, co polityczne. Trzeba jednak zaznaczyć, że obraz ów, zarysowany cokolwiek skrótowo, nie jest obrazem kompletnym. Z pewnością nie wystarcza, by zrozumieć całokształt światopoglądu Oakeshotta, co może być nadzieją czytelnika w chwili sięgania po książkę $e^{15}$. Jak polityka stanowi dla autora książki jedynie niewielką - i nie najważniejszą część ludzkiego doświadczenia, tak i książka ta nie stanowi najważniejszej

${ }^{13}$ W takim ujęciu nowożytność prezentuje się jako swego rodzaju nieprzekraczalna sytuacja bytowa i przeżycie egzystencjalne. Doświadczenie wolności leży w centrum tego przeżycia. „Owa skłonność do kultywowania «wolności» przyrodzonej w sprawstwie (zamiast nad nia utyskiwać) i do rozpoznawania postępowania w pojęciu autentyczności przemówiła zgiełkliwie w piętnastowiecznej Italii; w pismach Pico della Mirandoli stała się wręcz zasadą nowego obrazu «natury ludzkiej», której symbolem nie jest Adam ani Prometeusz, lecz Proteusz - postać znamienna z racji tego, że obdarzona niczym nie ograniczoną zdolnością samoprzemiany bez samozniszczenia; jej możliwości z nieporównaną wnikliwością i niedościgłym zapałem zeksplorował Rabelais; Cervantes stworzył bohatera, w którym fiasko wszelkich potyczek ze światem nie jest w stanie naruszyć jej jako aktu samostanowienia. Skłonność tę na sposób rozwiązły eksplorowali libertyni, Pascal rozpoznał ją jako otchłań samotności, a Buffcoat poczytał w swej naiwności za «prawo» każdego, «choćby i najbiedniejszego»". Tamże, s. 271-272.

14 Tamże, s. 37. O religii pisze Oakeshott jako o darze i rozpoznaje ją w sposób nieco przypominający fideizm Pascala czy Kierkegaarda. Tamże, s. 97-102.

15 Czytelnik może bowiem podążać za rozumieniem Straussa, postrzegającym filozofię polityki jako „wszystko obejmującą refleksję nad rzeczami ludzkimi”. L. Strauss, Czym..., s. 69. 
części jego dzieła. Choć wiele wątków zostaje w niej zasugerowanych, rozwinięcia trzeba szukać w innych pracach angielskiego myśliciela. W 0 postępowaniu człowieka Oakeshott, jako myśliciel XX-wieczny, opowiada jedynie pewną historię czasów nowożytnych. $\mathrm{W}$ ramach tej historii zadaje wiele trudnych pytań, nie udziela jednak na nie łatwych odpowiedzi.

M A R C I N P O L A K O W S K I 